\title{
Regulation of the RhoA/ROCK/AKT/ $\beta$-catenin pathway by arginine-specific ADP-ribosytransferases 1 promotes migration and epithelial-mesenchymal transition in colon carcinoma
}

\author{
GUANG-LIN SONG* , CONG-CONG JIN*, WEI ZHAO*, YI TANG, YA-LAN WANG, MING LI, \\ MING XIAO, XIAN LI, QING-SHU LI, XIAO LIN, WEN-WEN CHEN and JING KUANG \\ Department of Pathology, Molecular Medicine and Cancer Research Center, \\ Chongqing Medical University, Chongqing 400016, P.R. China
}

Received February 18, 2016; Accepted April 5, 2016

DOI: $10.3892 /$ ijo.2016.3539

\begin{abstract}
Arginine-specific ADP-ribosytransferases 1 (ART1) is able to modify the arginine of specific proteins by monoADP-ribosylation. We previously reported that the expression of ART1 in human colon adenocarcinoma tissues was higher than in adjacent tissues. Herein, we primarily revealed that ART1 could regulate the epithelial-mesenchymal transition (EMT) and, therefore, the development of colon carcinoma. In CT26 cells, which overexpressed ART1 by lentiviral transfection, the following were promoted: alterations of spindle-like non-polarization, expression of EMT inducers and mesenchymal markers, migration, invasion and adhesion. However, epithelial marker expression was decreased. Correspondingly, knockdown of ART1 in CT26 cells had the opposite effects. The effect of ART1 on EMT and carcinoma metastasis was also verified in a liver metastasis model of BALB/c mice. To further explore the molecular mechanism of ART1 in EMT, CT26 cells were treated with several specific inhibitors and gene silencing. Our data suggest that ART1 could regulate EMT by regulating the RhoA/ROCK1/AKT/ $\beta$-catenin pathway and its downstream factors (snaill, vimentin, $\mathrm{N}$-cadherin and E-cadherin) and that it therefore plays an important role in the progression of colon carcinoma.
\end{abstract}

\section{Introduction}

The epithelial-mesenchymal transition (EMT) was associated with tumor progression, especially the initiation of tumor

Correspondence to: Dr Ya-Lan Wang, Department of Pathology, Molecular Medicine and Cancer Research Center, Chongqing Medical University, Chongqing 400016, P.R. China

E-mail: wangyalan074@126.com

*Contributed equally

Key words: Arginine-specific ADP-ribosytransferases 1, epithelialmesenchymal transition, RhoA, $\beta$-catenin, colon carcinoma, invasion, metastasis metastasis. In the EMT process, the epithelial apico-basal polarity disappears, connections between cells decrease, actin cytoskeleton reorganizes, and cell morphology changes to spindle-like cells. These changes are beneficial for tumor cells to gain the ability to invade and metastasize. The molecular mechanisms of EMT could be due to the upregulation of EMT inducers (snail/slug, twist, and ZEB1) and mesenchymal markers (vimentin, and N-cadherin), and downregulation of epithelial markers (E-cadherin) (1-5).

ADP-ribosylation, which is catalyzed by ADP-ribosyltransferases, is a post-translational modification that is widely used to regulate the function of proteins. ADP-ribosyltransferases cleave the glycosidic bond between nicotinamide with the adjacent ribose in the $\mathrm{NAD}^{+}$molecule and then transfer the ADP-ribose moiety to specific amino acids of proteins. These enzymes include mono-ADP-ribosyltransferases (mARTs) and poly-ADP-ribose polymerases (PARPs), which transfer a single ADP-ribose and polymers of ADP-ribose to substrates, respectively $(6,7)$. Many studies have reported that PARPs are closely related to cell proliferation, apoptosis, migration, invasion, angiogenesis and inflammation (8-13). Although the modification of mono-ADP-ribosylation is more common than poly-ADP-ribosylation in cells, few studies have been performed, especially in tumors (14). Arginine-specific mono-ADP-ribosytransferase 1 (ART1) belongs to the monoADP-ribosyltransferase family. It is present in humans, mice and rats $(15,16)$, and it is involved in the modification of proteins, such as FGF-2, TNF- $\alpha$, HNP-1, PDGFBB, and integrin $\alpha 7 \beta 1$. The biological effects of ART1 may be related to cell proliferation, apoptosis, inflammation, angiogenesis and cell adhesion in non-tumor cells (17-21). We previously reported that ART1 could enhance proliferation and inhibit apoptosis in colon carcinoma (22-24). However, whether ART1 could influence migration through EMT in colon carcinoma and what the concrete mechanism is has not been reported.

In this study, we showed that the change of ART1 expression in CT26 cells could affect the expression of EMT inducers, mesenchymal markers and epithelial markers and then influence the invasion and metastasis in vitro and in vivo. ART1 may be a new regulatory factor for EMT, and it is expected to become a potential therapeutic target for colorectal carcinoma. 


\section{Materials and methods}

Cell lines and animals. CT26 cells, a murine colon adenocarcinoma cell line, were a gift of Professor Yu-Guan Wei (West China Hospital, Chengdu, China). Lentivirus that express the mouse ART1 cDNA or a short hairpin RNA (shRNA) against ART1 were respectively constructed by Genechem (Shanghai, China) and were effectively transfected into CT26 cells, as previously described $(22,25)$. The experimental groups included overexpression of ART1 in CT26 cells (GFP-ART1 group) and silencing of ART1 in CT26 cells (GFP-shART1 group); untransfected CT26 cells (non-transfection group) and CT26 cells transfected with empty lentivirus vector (GFP-vector group) were used as the control groups. BALB/c mice were obtained from Experimental Animal Center of National Bio-industry Base in Chongqing.

Cell culture. The CT26 cells were cultured in RPMI-1640 medium (Hyclone, Logan, UT, USA) with $10 \%$ fetal bovine serum (FBS) (Sijiqing, Hangzhou, China) under appropriate humidity conditions $\left(5 \% \mathrm{CO}_{2}, 37^{\circ} \mathrm{C}\right)$.

Viral infection. Adenovirus (Ad)-si- $\beta$-catenin was obtained from Jia-Yi Huang (Departments of Pathophysiology, Chongqing Medical University, Chongqing, China). The transfection was performed as previously described (26). The efficiency of Ad-si- $\beta$-catenin transfection was verified by reverse transcription-PCR (RT-PCR) and western blot analysis.

Reverse transcription-PCR analysis. Total CT26 cellular mRNA in each group was extracted with TRIzol reagent (Takara, Dalian, China) and we used an RT-PCR kit (Takara) for reverse transcription. The primers were as follows: $\beta$-catenin, 5'-caatcaagagagcaagctcatc-3' (F) and 5'-agtcgctgactt gggtctgt-3' (R) and $\beta$-actin, $5^{\prime}$-caccegcgagtacaaccttc- $3^{\prime}(\mathrm{F})$ and 5'-cccatacccaccacacc-3' (R) (Sangon Biotech Co., Shanghai, China). The conditions of reverse transcription included reaction at $56^{\circ} \mathrm{C}$ for $45 \mathrm{~min}$ and $95^{\circ} \mathrm{C}$ for $3 \mathrm{~min}$, and the conditions of extension were repeated 30 cycles at $95^{\circ} \mathrm{C}$ for $30 \mathrm{sec}, 60^{\circ} \mathrm{C}$ for $30 \mathrm{sec}$ and $72^{\circ} \mathrm{C}$ for $60 \mathrm{sec}$. Electrophoresis on $2 \%$ agarose gels (Genview, Tallahassee, FL, USA) was used to detect the PCR amplification products.

Detection of cell morphology by hematoxylin-eosin staining ( $H \& E$ staining). Cells were incubated on cover slips, washed with phosphate-buffered saline (PBS), fixed with 95\% ethanol for $20 \mathrm{~min}$, and stained with hematoxylin-eosin. Each cover slip was detected by microscopy (Nikon Corp., Tokyo, Japan).

Detection of actin polymerization assay. CT26 cells were seeded on cover slips. Each cover slip was washed three times with PBS and fixed in 4\% paraformaldehyde for $20 \mathrm{~min}$. Then, cells were treated with $0.1 \%$ Triton $\mathrm{X}-100$ for $15 \mathrm{~min}$ at room temperature and blocked with $5 \%$ bovine serum albumin (BSA) for $30 \mathrm{~min}$ at $37^{\circ} \mathrm{C}$. Then, the cells were incubated with $0.5 \%$ rhodamine-phalloidin (Sigma, St. Louis, MO, USA) $30 \mathrm{~min}$ at room temperature. Finally, each cover slip was sealed with an anti-fluorescence quenching agent (Beyotime, Shanghai, China) and was observed with confocal microscopy (Leica TCS SP2, Leica Microsystems GmbH, Germany).
Flow cytometry method $(F C M)$. Cells $\left(1 \times 10^{6} / 1\right)$ were digested by $0.25 \%$ trypsin, fixed with $4 \%$ paraformaldehyde for 40 min, washed with PBS and blocked with 5\% BSA for $30 \mathrm{~min}$. Then, cells were centrifuged at $800 \mathrm{rpm}$ for $5 \mathrm{~min}$. Half a percent of phalloidin-rhodamine $(200 \mu \mathrm{l})$ was used to re-suspend the cell precipitate, which was incubated for 30 min. Finally, cells were washed three times with PBS and we detected the average fluorescence intensity by flow cytometry (FACSVantage SE, Becton-Dickinson Co., Franklin Lakes, NJ, USA).

Wound healing assay. Cells (1x10\%/l) were cultured in 6-well plates. When cells proliferated to form a full layer in each well, the cells in the middle of each well were scraped and washed away with PBS for creating a channel in the middle of each well. After being cultured in RPMI-1640 containing 0.5\% FBS for $24 \mathrm{~h}$, the changes in the width of the channel, which presented the migration ability in each group, were detected by microscopy (Nikon Corp.).

Invasion assay. The upper surface of the polycarbonate membrane was paved with Matrigel (Becton-Dickinson Co.) and the chamber was treated with $0.6 \mathrm{ml}$ medium containing $10 \%$ FBS. Cells $\left(5 \times 10^{5}\right)$ were grown onto the upper chamber with $0.2 \mathrm{ml}$ serum-free medium. Cells were fixed with $4 \%$ paraformaldehyde after being incubated for $20 \mathrm{~h}$. Then, a cotton swab was used to wipe the cells from the upper chamber. Cells on the lower surface of the chamber were stained with crystal violet. The number of cells that had migrated into the lower surface of chamber was counted in random selection, five times magnification, without repetition.

Adhesion assay. A 96-well plate was prepared with $10 \mathrm{mg} / \mathrm{l}$ fibronectin (FN) overnight at $4^{\circ} \mathrm{C}$ and $1 \%$ BSA was used to block the $\mathrm{FN}$ for $2 \mathrm{~h}$. One hundred microliters of $10 \%$ FBS medium with cells $\left(1 \times 10^{5}\right)$ was added to the plate, which was then incubated at $5 \% \mathrm{CO}_{2}$ and $37^{\circ} \mathrm{C}$. The floating cells were washed off with PBS after $2 \mathrm{~h}$. One hundred microliters of medium containing $10 \mu \mathrm{l}$ cell counting kit-8 solution (CCK-8, Dojindo, Kumamoto, Japan) was added to each well and then incubated for $2 \mathrm{~h}$ at $37^{\circ} \mathrm{C}$. Finally, the $\mathrm{OD}$ value was measured by the absorbance at $450 \mathrm{~nm}$ with a microplate reader (Bio-Rad, CA, USA).

Western blot analysis. The total or nuclear proteins of CT26 cells in each group and mouse transplantation tumor tissues were extracted by the total and nuclear protein extraction kit (Beyotime), and the concentration of protein was detected with a bicinchoninic acid (BCA) protein assay kit (Beyotime). All of the proteins were separated in SDS-PAGE gel and transferred to PVDF membranes (Millipore, MA, USA) by electrophoresis. The membranes were blocked with 5\% non-fat milk for $1 \mathrm{~h}$ and incubated with primary antibodies against ART1 (Abgent Technology, San Diego, CA, USA), $\beta$-catenin (Santa Cruz Biotechnology, Santa Cruz, CA, USA), $\mathrm{N}$-cadherin, E-cadherin (Bioworld Technology, St. Louis, MO, USA), Histone 2B, vimentin, ROCK1 (Proteintech Group, Chicago, IL, USA), AKT, phospho-Akt (Ser473), GSK-3 $\beta$, phospho-GSK-3 $\beta$ (Ser9) (Cell Signaling Technology, Boston, MA, USA), $\beta$-actin (Bioss, Shanghai, China) at $4^{\circ} \mathrm{C}$ overnight, respectively. Peroxidase-conjugated goat anti-rabbit IgG 

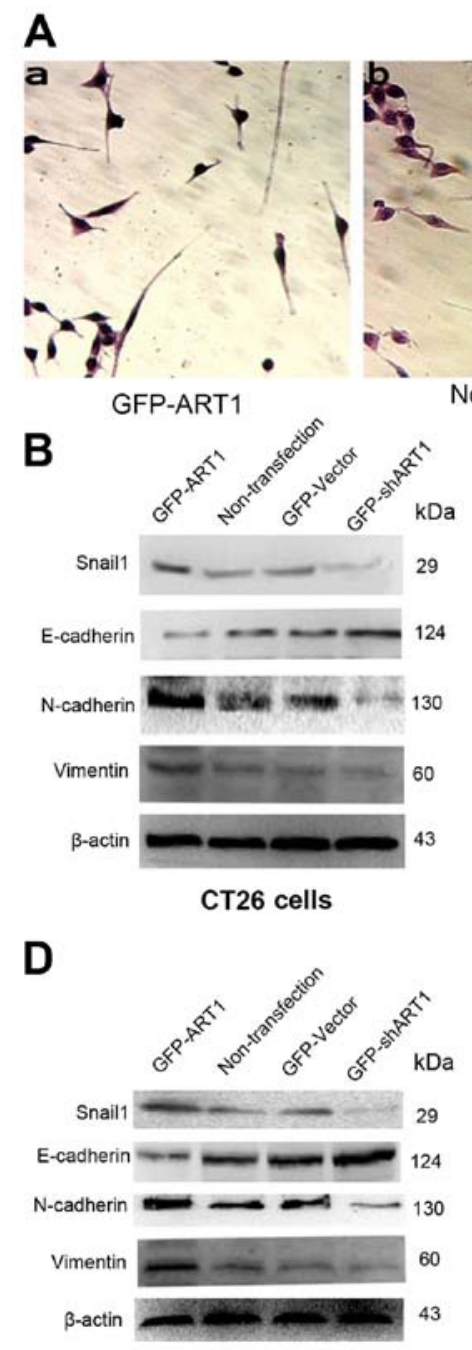

Intrasplenic tumor of CT26 cells

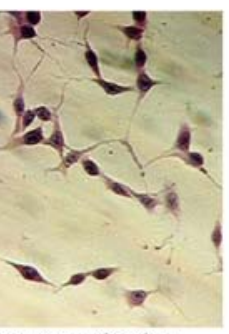

Non-transfection

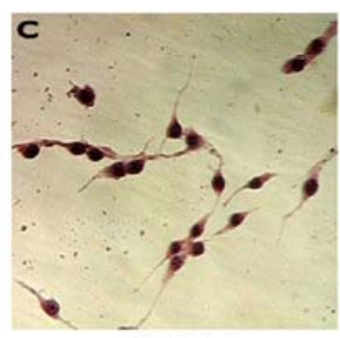

GFP-Vector

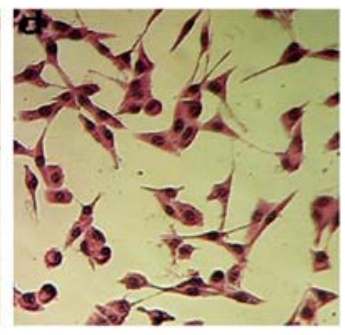

GFP-shART1

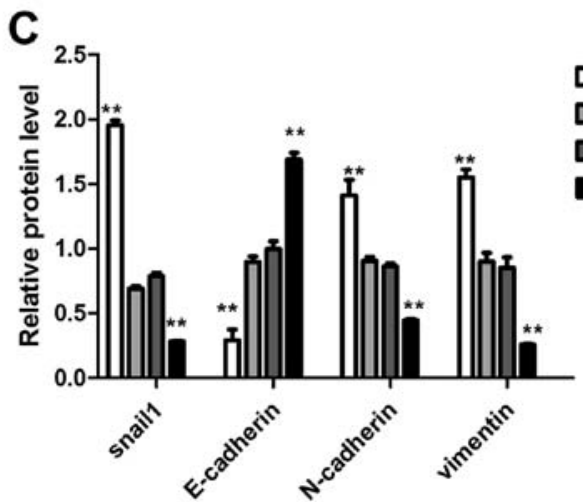

E

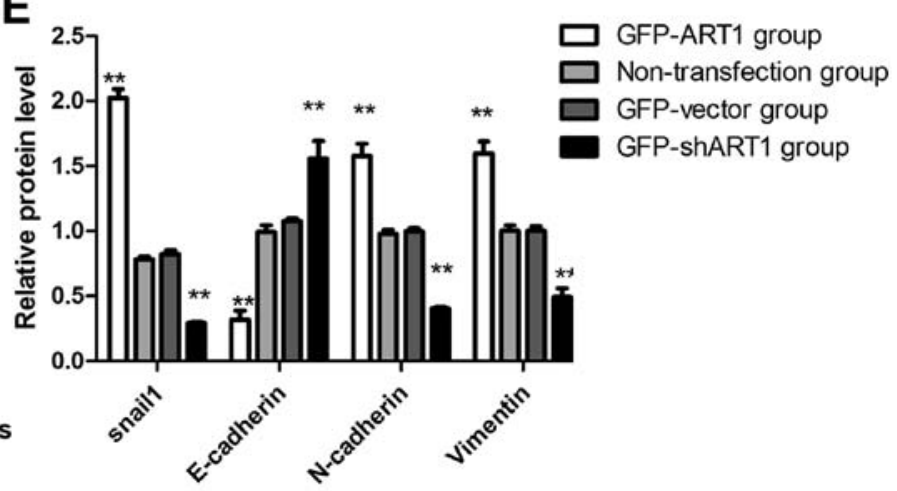

Figure 1. Effects of ART1 on the change of CT26 cell morphology and the expressions of proteins related to EMT. (A) CT26 cells with H\&E staining (x200 magnifications). Compared with the GFP-vector (c) and non-transfection CT26 cells (b), GFP-ART1 CT26 (a) cells showed non-polarized or mesenchymallike cell morphology; while GFP-shART1 CT26 cells (d) showed apical-basal polarized or epithelioid cell morphology. (B and C) Expression of vimentin, N-cadherin, and snail showed a significant increase in the GFP-ART1 CT26 cells and displayed a decrease in the GFP-shART1 CT26 cells, compared with the GFP-vector and non-transfection CT26 cells $\left({ }^{* *} \mathrm{p}<0.01\right)$. However, the expression of E-cadherin changed in the opposite direction $\left({ }^{* *} \mathrm{p}<0.01\right)$. (D and E) Protein was extracted from the intrasplenic transplantation tumor of CT26 cells. The expression of snaill, vimentin and N-cadherin had an observable decline in the GFP-shART1 group and significant increase in the GFP-ART1 group, as well as in vitro, compared with GFP-vector and non-transfection groups (** $<<0.01)$. The expression level of E-cadherin had the opposite change $\left({ }^{* *} \mathrm{p}<0.01\right)$.

(Bioss) was used to incubate these membranes for $2 \mathrm{~h}$ at room temperature. Finally, the membranes were examined with enhanced chemiluminescence reagents (ECL) (Beyotime) and analyzed using Quantity One software.

Tumor transplantation model. BALB/c mice (Mus musculus Linnaeus) (female, 6-8 weeks old, and 18-22 g) were used. CT26 cells $\left(1 \times 10^{7} / \mathrm{ml}\right)$ were collected from each group. Each mouse, which was anesthetized by $2 \%$ chloral hydrate $(0.3 \mathrm{~g} / \mathrm{kg})$ intraperitoneal injection, was injected with $5 \times 10^{5}$ CT26 cells into the splenic capsule. These mice were executed following 2 weeks of feeding after they were injected CT26 cells. Furthermore, the number of liver metastasis nodules and the liver weights were recorded respectively. Tumors from the spleen were used to extract protein for western blot analysis (28).
Statistical analysis. The above experiments were all repeated three times each. Data were analyzed using SPSS 18.0 software (SPSS, Chicago, IL, USA). The values are represented as the means \pm standard deviation $(\mathrm{SD})$ (mean $\pm \mathrm{SD}$ ). Differences between each group were analyzed with one-way ANOVA or the Student's t-test. P-value $<0.05$ was identified as a statistically significant difference.

\section{Results}

Effects of ART1 on the CT26 cell morphology. Cell morphological changes were observed under optical microscope with H\&E staining. Compared to non-transfection CT26 cells and GFP-vector CT26 cells, GFP-ART1 CT26 cells showed spindle-like morphology, while most of GFP-shART1 CT26 cells showed epithelioid morphology (Fig. 1A). 
A

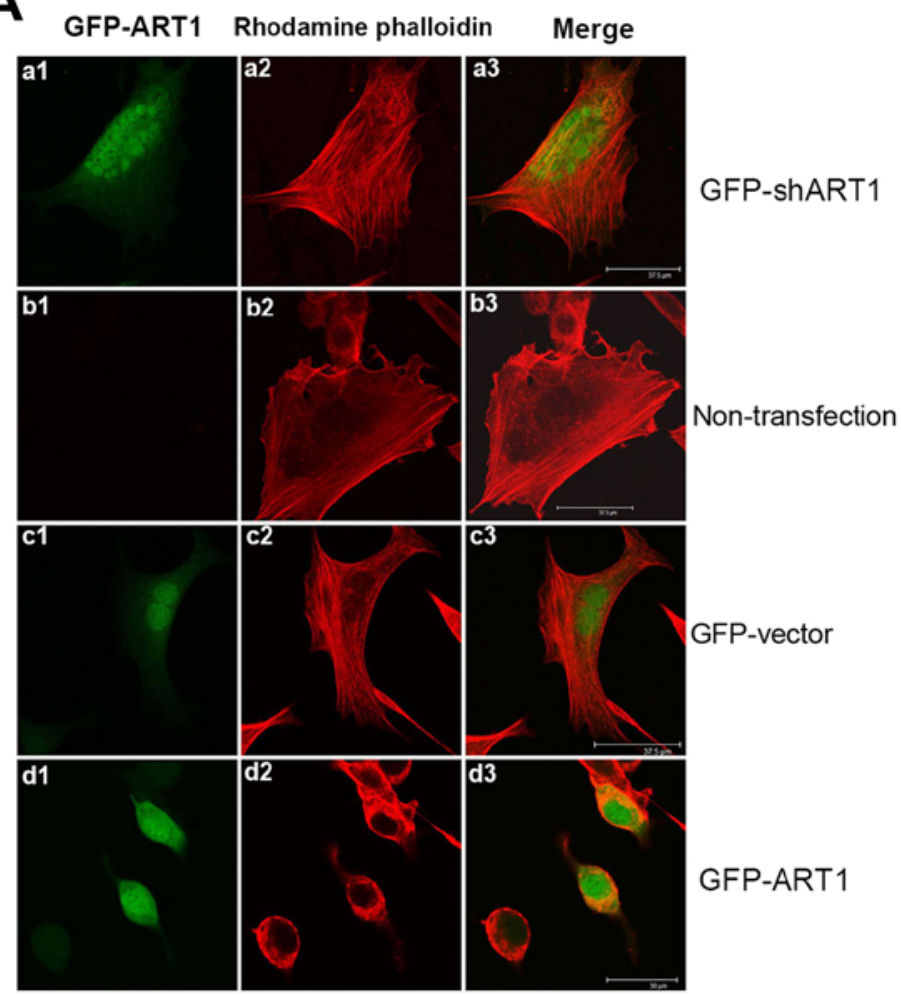

B
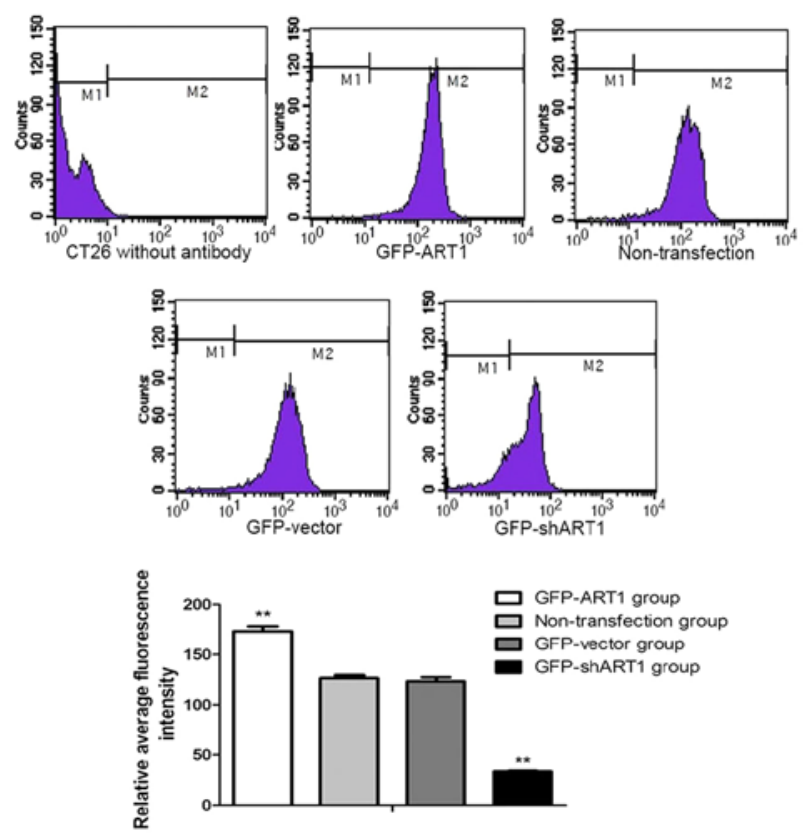

Figure 2. (A) Rhodamine-phalloidin staining of F-actin (microfilament) observed with confocal laser scanning microscopy. The GFP-ART1 CT26 cells (d1-d3) displayed a mesenchymanl-like phenotype with more ordered and bunched microfilaments, the GFP-shART1 CT26 cells (a1-a3) showed an epithelioid phenotype with fewer and disordered microfilaments, compared to the non-transfection (b1-b3) and GFP-vector CT26 cells (c1-c3). (B) Expression of F-actin after transfection by FCM. x-axis, fluorescence intensity; y-axis, number of cells. M1 area, cells without fluorescence; M2 area, cells with fluorescence.

Effect of ART1 on the expression of proteins related to EMT in vitro and in vivo. The expressions of snaill, vimentin and N-cadherin in the GFP-ART1 group were significantly increased, compared to the non-transfection and GFP-vector groups in vitro and in vivo $(\mathrm{p}<0.05)$. In contrast, expression of these proteins in the GFP-shART1 group was significantly deceased, compared to the control groups in vitro and in vivo. However, the expression of the epithelial marker E-cadherin was reduced in the GFP-ART1 groups and increased in the GFP-shART1 groups compared to other control groups in vitro and in vivo $(\mathrm{p}<0.05)$ (Fig. 1B-E).

Effects of ART1 on the change of actin in CT26 cells. Using confocal laser scanning microscopy, a disordered actin network and fewer actin fibers in the cytoplasm were detected in the GFP-shART1 CT26 cells. However, the GFP-ART1 CT26 cells had an ordered actin network and more actin fibers compared with the control groups (Fig. 2A). To quantify the effect of ART1 on actin, the fluorescence intensity of F-actin was detected with FCM. The mean fluorescence intensity of F-actin in the GFP-ART1 CT26 cells was enhanced and it in the GFP-shART1 CT26 cells was diminished $(\mathrm{p}<0.01)$ (Fig. 2B).

Effects of ART1 on adhesion, movement and invasion of CT26 cells. The change of ART1 was found to affect the adhesion, movement and invasion in CT26 cells. Compared with the control groups, GFP-ART1 CT26 cells showed that the rate of cell adhesion, migration distance and the numbers of CT26 cells which migrated to the chamber membrane were all increased $(\mathrm{p}<0.05)$, while CT26 cells with silenced ART1 showed an obviously opposite trend ( $<<0.01)$ (Fig. 3).

Effect of ART1 on liver metastases of CT26 cells in BALB/c mice. To investigate whether ART1 could affect the metastasis of CT26 cells in vivo, we successfully generated a liver metastasis model of BALB/c mice through injecting CT26 cells into the splenic capsule, the mice were sacrificed after two weeks, the liver weighed and the metastatic nodules in the liver counted. We observed that each GFP-ART1 group had $\geq 20$ white nodules of metastatic carcinoma, while in each GFP-shART1 group only 1-2 nodules of metastatic carcinoma was observed $(\mathrm{p}<0.01)$ (Fig. 4A and B). Compared to the GFP-vector group and non-transfection group, the liver weight was much heavier in the GFP-ART1 group and lighter in the GFP-shART1 group ( $<<0.01)$ (Fig. 4C). Therefore, the change in the ART1 dose appears to play a role in colon carcinoma metastasis in vivo.

Effect of ART1 on the expression levels of RhoA, ROCK1, phospho-Akt ${ }^{\text {Ser473 }}$, and phosphor-GSK-3 $\beta^{\text {Ser } 9}$ in vitro and in vivo. Significant increases in the expression of RhoA, ROCK1, phospho-Akt ${ }^{\text {Ser473 }}$, phosphor-GSK-3 $\beta^{\text {Ser9 }}$ were observed in the GFP-ART1 group compared to the nontransfection and GFP-vector groups $(\mathrm{p}<0.05)$. In contrast, the expression of these proteins in the GFP-shART1 group was 
A

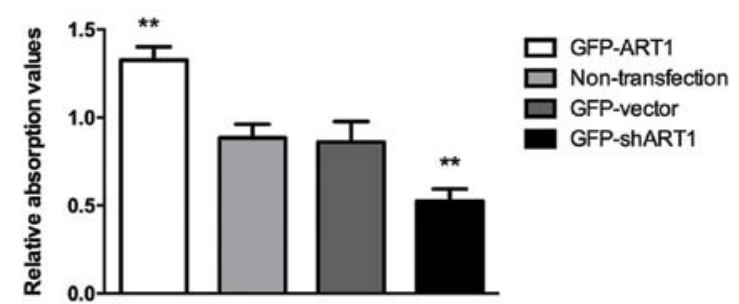

B

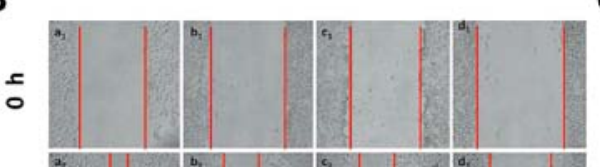

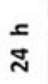
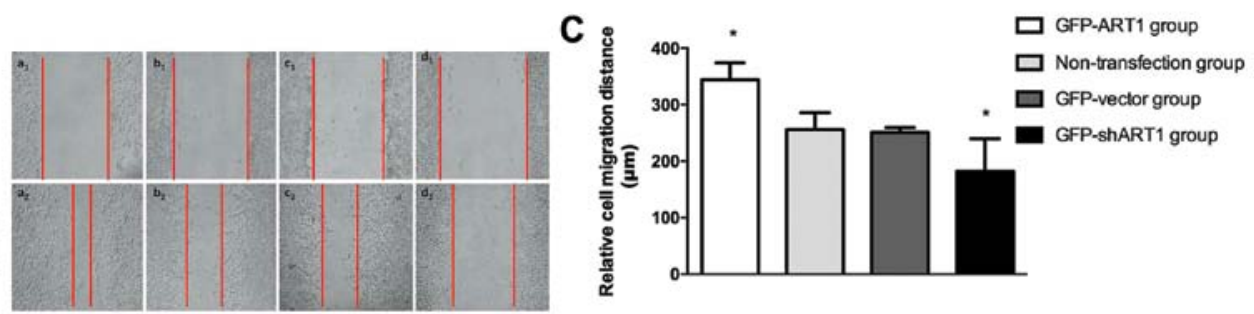

D

GFP-ART1 Non-transfection GFP-Vector GFP-shART1

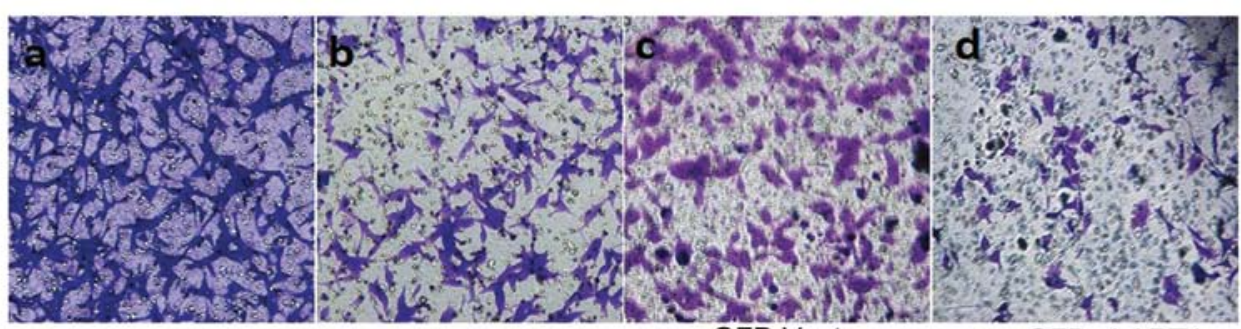

E

GFP-ART1

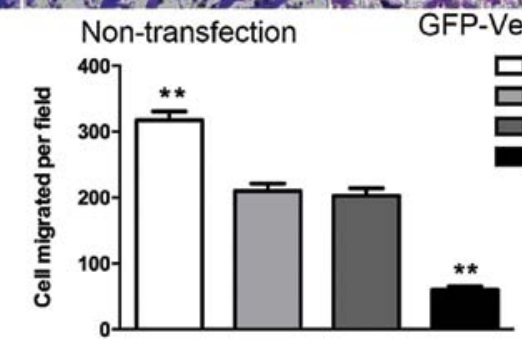

$\square$ GFP-ART1 group

GFP-ShART1

Figure 3. Effects of ART1 on adhesion, migration and invasion of CT26 cells. (A) Cell adhesion assay. Compared with the GFP-vector and non-transfection CT26 cells, the absorbance value at $490 \mathrm{~nm}$ was significantly decreased in the GFP-shART1 CT26 cells and was increased in the GFP-ART1 CT26 cells $\left({ }^{* *} \mathrm{p}<0.01\right)$. (B and C) Cell wound healing assay ( $\mathrm{x} 40$ magnifications). The migration distance of CT26 cells showed a significant increase in the GFP-ART1 CT26 cells (a1 and a2) and indicated an observable decrease in the GFP-shART1 CT26 cells (d1 and d2) compared with the GFP-vector (c1 and c2) and non-transfection CT26 cells (b1 and b2) ( $*$ p $<0.01)$. (D and E) Transwell invasion assay (x200 magnification). The number of CT26 cells through the Matrigelcoated chamber membrane was observably declined in the GFP-shART1 CT26 cells (d) and there was a marked increase in the GFP-ART1 CT26 cells (a) compared with the GFP-vector (c) and non-transfection CT26 cells (b) ("p<0.05).

\section{A}

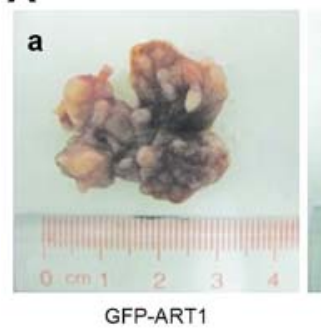

B

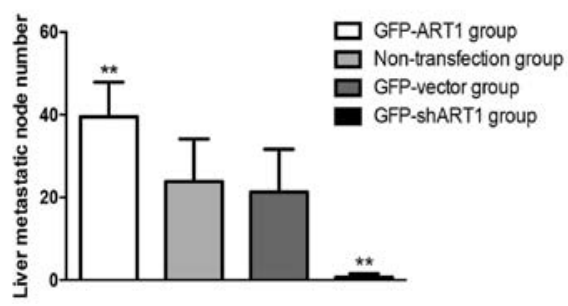

Non-transfection

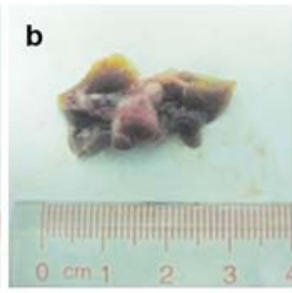

\section{C}

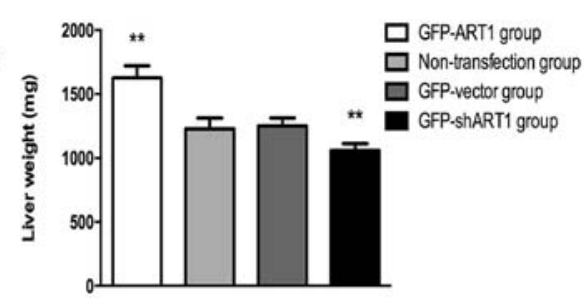

Figure 4. Effects of ART1 on liver metastasis in BALB/c mice. Intrasplenic transplantation tumor model was constructed to observe liver metastasis. Compared with the GFP-vector and non-transfection groups, the GFP-ART1 group showed an observable promotion of tumor metastasis with heavier liver weight and more metastasis nodules, the GFP-shART1 group had a significant inhibition of the liver metastasis with lighter liver weight and fewer metastasis nodules $(* \mathrm{*}<0.01)$. 


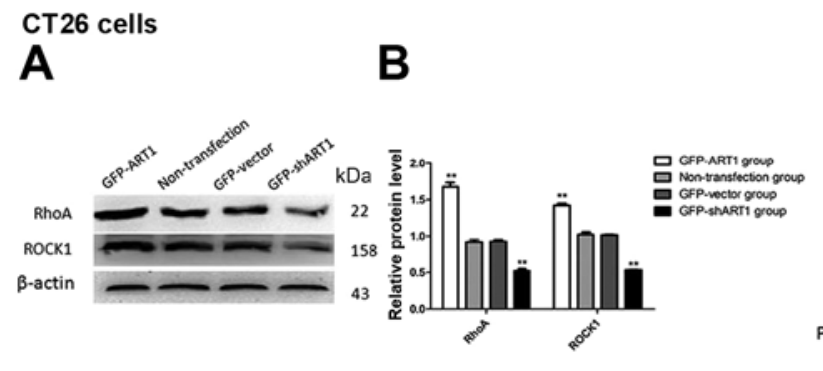

$\mathbf{E}$

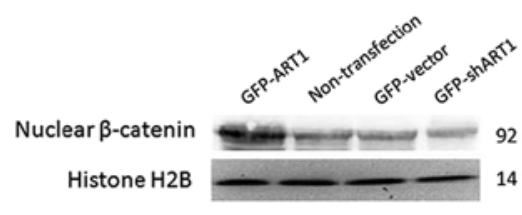

C

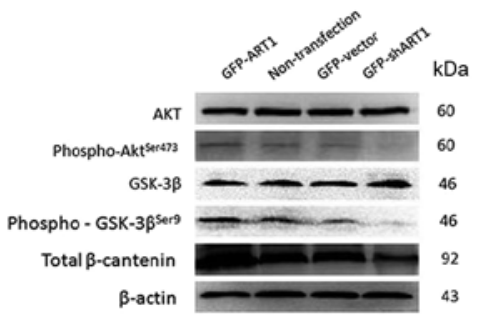

D

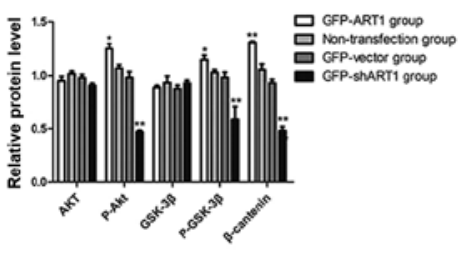

$\mathbf{F}$
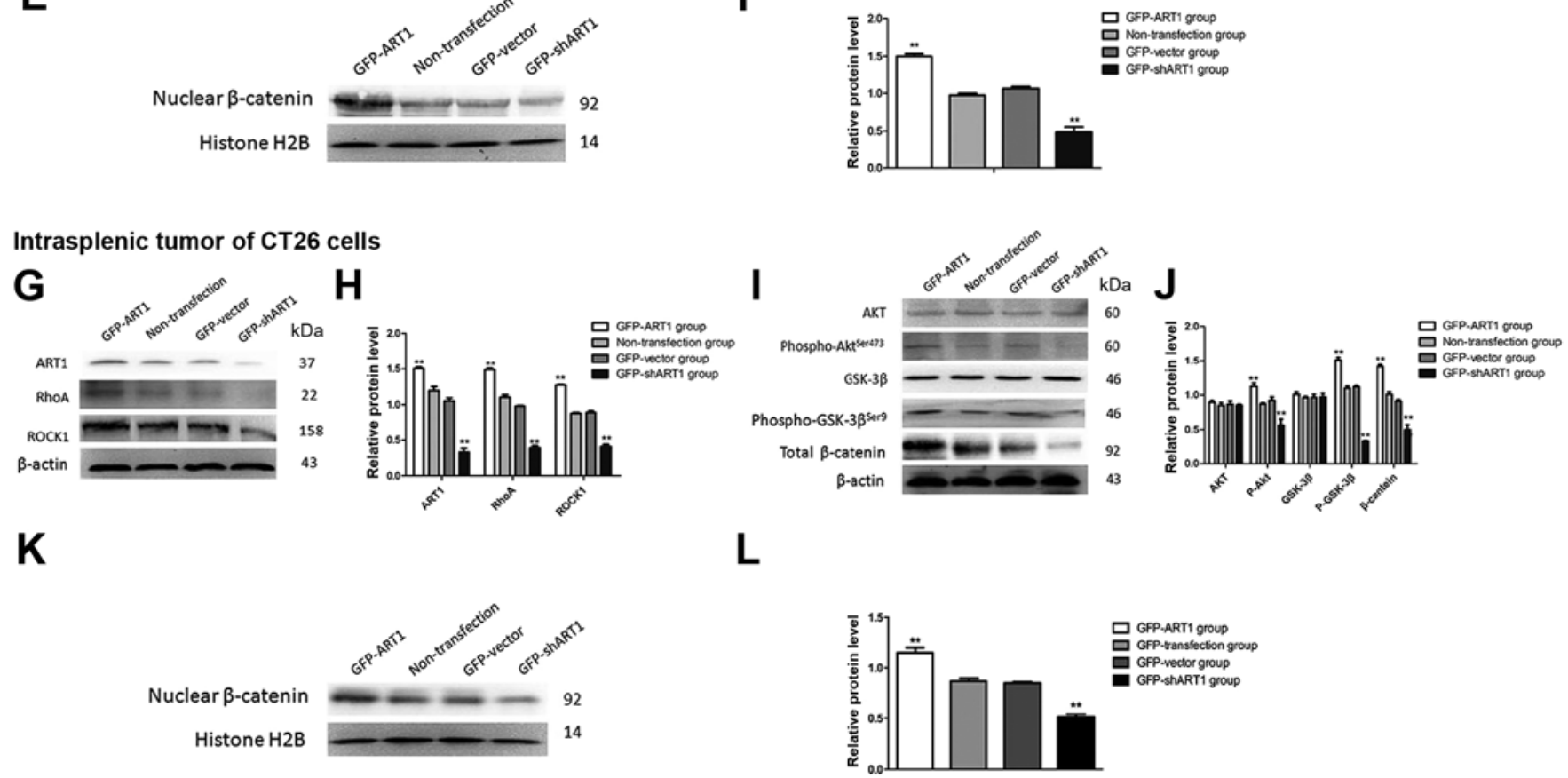

Figure 5. Expression of RhoA, ROCK1, phospho-Akt ${ }^{\mathrm{Ser} 473}$, phospho-GSK-3 $\beta^{\mathrm{Ser} 9}$, total and nuclear $\beta$-catenin detected by western blotting in vitro and in vivo. (A-F) Expression of RhoA, ROCK1, phospho-Akt ${ }^{\text {Ser473 }}$, phospho-GSK-3 $3 \beta^{\text {Ser9 }}$, total and nuclear $\beta$-catenin showed a significant increase in the GFP-ART1 CT26 cells and displayed a decrease in the GFP-shART1 CT26 cells compared with the GFP-vector and non-transfection CT26 cells (** $\mathrm{p}<0.01)$. The expression of non-phosphorylation AKT and GSK-3 $\beta$ were not significantly different among each group (p>0.05). (G-L) Protein was extracted from the intrasplenic transplantation tumor of CT26 cells. The expression of ART1, RhoA, ROCK1, phospho-Akt ${ }^{\text {Sert73 }}$, phospho-GSK-3 $\beta^{\text {Ser9 }}$, total and nuclear $\beta$-catenin also had an observable decline in the GFP-shART1 group and significant increase in the GFP-ART1 group, compared with GFP-vector and non-transfection groups $(" \mathrm{p}<0.01)$. The expression of non-phosphorylation AKT and GSK-3 $\beta$ were not observably different among each group $(\mathrm{p}>0.05)$.

significantly deceased compared to the control groups $(\mathrm{p}<0.05)$. Non-phosphorylation of AKT and GSK-3 $\beta$ were no significantly different in these groups ( $>00.05$ ) (Fig. 5A-D and G-J).

Effect of ART1 on the expression of $\beta$-catenin in vivo and in vitro. The results of western blot analysis showed that there was an increase in both expression levels of the total $\beta$-catenin and nuclear $\beta$-catenin in the GFP-ART1 group $(\mathrm{p}<0.01)$. Expression of the total $\beta$-catenin and nuclear $\beta$-catenin were decreased in the GFP-shART1 group (p<0.01) (Fig. 5E, F, K and $\mathbf{J}$ ).

Effects of LY294002 and Y27632 on the expression of ART1, ROCK1 and phospho-Akt ${ }^{\text {Ser473 }}$ in CT26 cells. To further verify that ART1 could regulate EMT via the RhoA/ROCK1/ AKT pathway, non-transfection CT26 cells were treated with Y27632 (an inhibitor of ROCK1) and LY294002 (a specific competitive inhibitor of PI3K), respectively. When the non-transfection CT26 cells was treated with Y27632, the expression of phospho-Akt ${ }^{\mathrm{Ser} 733}$ was decreased, compared to the non-transfection CT26 cells without Y27632 ( $p<0.01)$, while the expressions of non-phosphorylated Akt were not significantly different between the treated and untreated Y27632 non-transfection CT26 cells ( $\mathrm{p}>0.05$ ) (Fig. 6A and B). We also found that the expression of phospho- $\mathrm{Akt}^{\mathrm{Ser} 473}$ was significantly downregulated in the non-transfection CT26 cells treated with LY294002 compared with the untreated group $(\mathrm{p}<0.01)$, but non-phosphorylation-Akt and ROCK1 were not observably different between the treated and untreated LY294002 non-transfection CT26 cells ( $>00.05)$ (Fig. 6C and D).

Effects of LY294002 on the expression levels of phospho$A k t^{\text {Ser473 }}$ and $\beta$-catenin in GFP-ART1 CT26 cells. Western blotting showed that the expression levels of phospho$\mathrm{Akt}^{\mathrm{Ser} 473}$ and $\beta$-catenin in GFP-ART1 CT26 cells treated with 
A

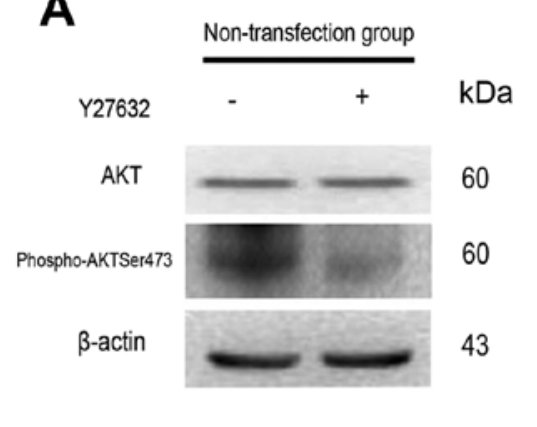

C

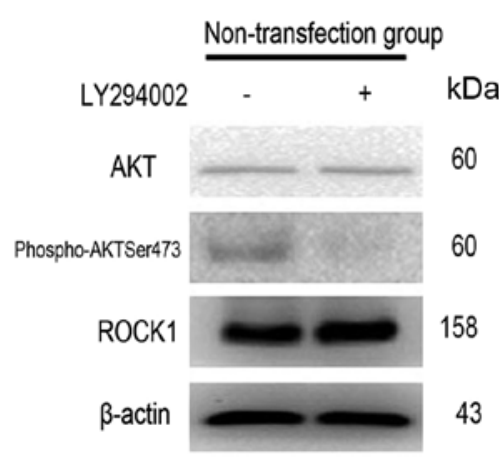

B

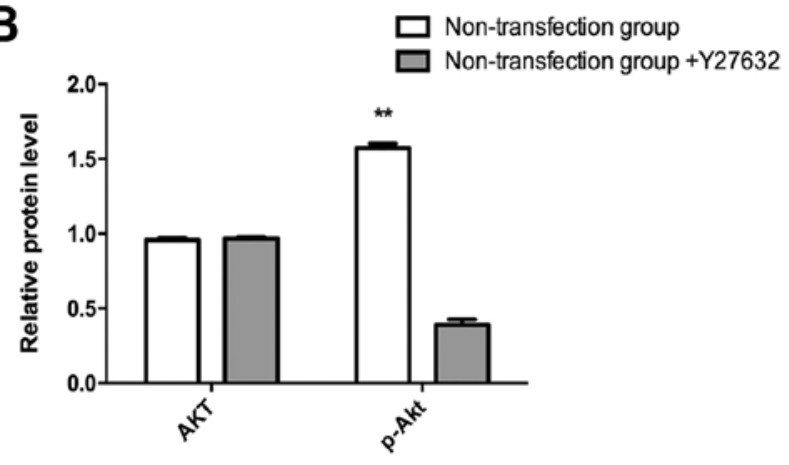

D

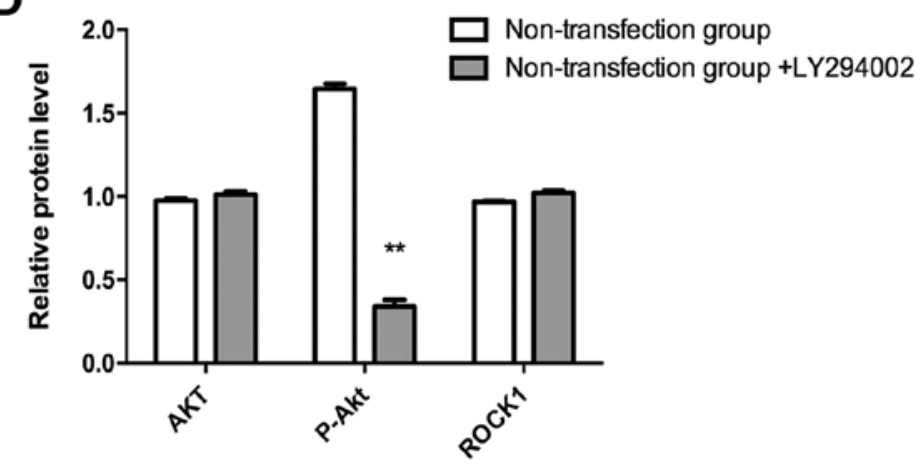

Figure 6. Effects of LY294002 and Y27632 on CT26 cells. (A and B) The expression of phospho-Akt ${ }^{\text {Ser473 }}$ showed a significant decline in the non-transfection CT26 cells treated with Y27632, compared with non-transfection CT26 cells without Y27632 ("p $<0.01$ ). However, the expression of non-phosphorylated AKT showed no observable difference between Y27632 treated and untreated non-transfection CT26 cells ( $\mathrm{p}>0.05)$. (C and D) The expression of phospho-Akt ${ }^{\text {Ser473 }}$ was observably decreased in the non-transfection CT26 cells treated with LY294002, compared with non-transfection CT26 cells without LY294002 $(\stackrel{*}{*}<0.01)$. The expression of non-phosphorylation AKT showed no significant difference between the LY294002 treated and untreated non-transfection CT26 cells $(\mathrm{p}>0.05)$.

LY294002 were lower than it in the GFP-ART1 CT26 cells without LY294002 (p<0.01) (Fig. 7A and B).

Effect of silencing $\beta$-catenin on the expression levels of snaill, $N$-cadherin, vimentin and E-cadherin in GFP-ART1 CT26 cells. To further verify that ART1 could be responsible for EMT through regulating the expression of $\beta$-catenin, Ad-si$\beta$-catenin and Ad-RFP-vectors were successfully infected into GFP-ART1 CT26 cells (Fig. 7C). The efficiency of adenovirus vector-mediated siRNA interference in suppressing $\beta$-catenin in GFP-ART1 CT26 cells was detected by RT-PCR and western blot analysis. These methods showed that both of the mRNA and protein levels of $\beta$-catenin in GFP-ART1 CT26 cells transfected with $\beta$-catenin-si RNA were decreased $(\mathrm{p}<0.01)$ (Fig. 7D-G). The results of western blot analysis also showed that there were increases in the expression levels of snaill, $\mathrm{N}$-cadherin, and vimentin and a decrease in expression of E-cadherin in the GFP-ART1-Ad-RFP-si- $\beta$-catenin GFP-ART1 CT26 cells compared with the GFP-ART1Ad-RFP-vector GFP-ART1 CT26 cells $(\mathrm{p}<0.01)$ (Fig. 7F and $G)$.

Effect of the Ad-RFP-si- $\beta$-catenin on the migration and invasion of GFP-ART1 CT26 cells. The migration distance detected by the wound healing assay was decreased in the GFP-ART1Ad-RFP-si- $\beta$-catenin GFP-ART1 CT26 cells compared with the GFP-ART1-Ad-RFP-vector GFP-ART1 CT26 cells $(\mathrm{p}<0.01)$ (Fig. 8A and B). Concomitantly, the invasive ability of the GFP-ART1-Ad-RFP-si- $\beta$-catenin GFP-ART1 CT26 cells decreased, compared to the GFP-ART1-Ad-RFP-vector GFP-ART1 CT26 cells (p<0.01) (Fig. 8C and D).

\section{Discussion}

EMT is considered to play an important biological role in cancer. It could stimulate the transformed cells to lose the ability for cell-cell adhesion, while gaining increased cell motility and invasion. The features of EMT have been observed in many cancers, such as colon, ovarian, breast, and esophageal cancer. The integrin-extracellular matrix (ECM) interaction is an important signaling pathway in regulating the change between transformed cells and metastatic cells during the process of EMT. Integrins, which include 24 distinct integrin heterodimers that consist of $18 \alpha$-subunits and $8 \beta$-subunits, are heterodimeric cell-surface receptors (27). In breast cancer and melanoma cells, integrin $\alpha 7 \beta 1$ could interact with laminin and activate the RhoA signaling cascade to promote tumor invasion (28-30). Researchers have reported that mono-ADPribosylation of integrin $\alpha 7 \beta 1$ catalyzed by ART1 takes place in differentiated myotubes and this post-translational modification could activate integrin $\alpha 7 \beta 1$ and then increase its affinity to laminin (31). Hence, ART1 is likely to be involved in the process of EMT. Our previous studies have shown that the level of ART1 expression in human colon adenocarcinoma 
A

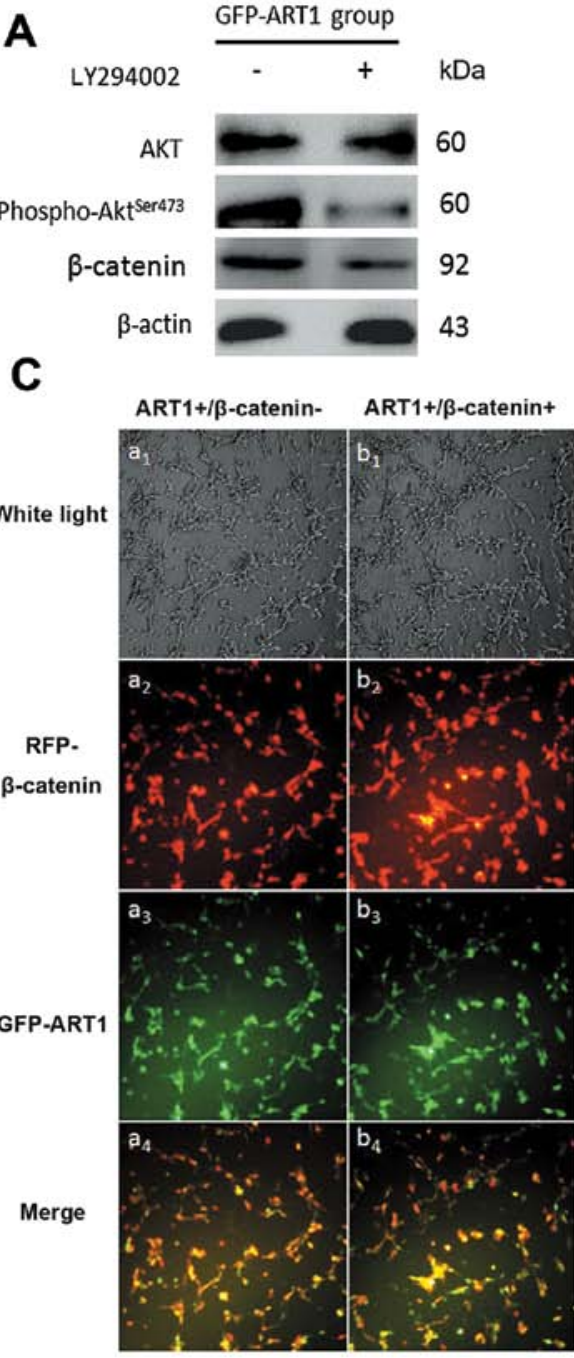

$\mathbf{F}$

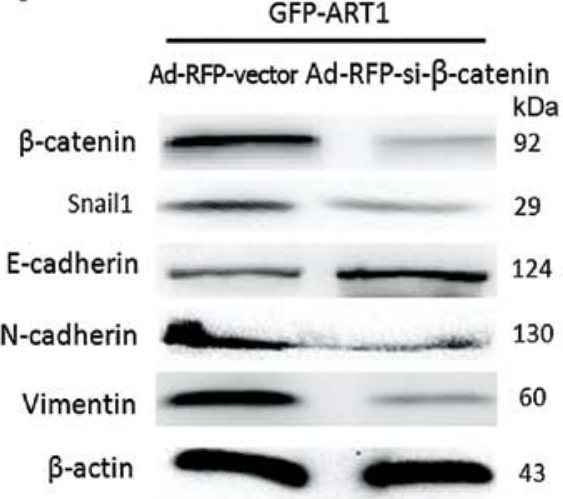

B
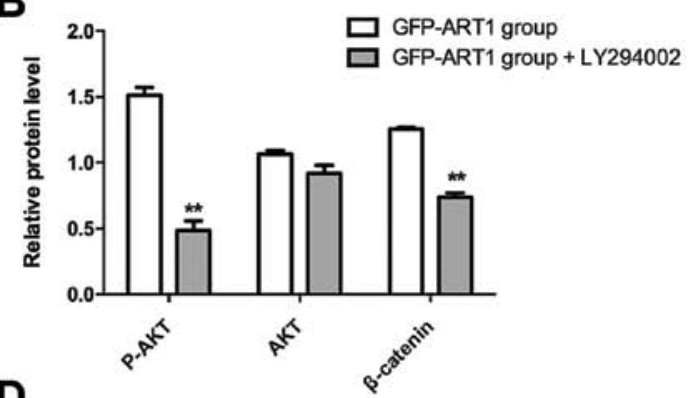

GFP-ART1

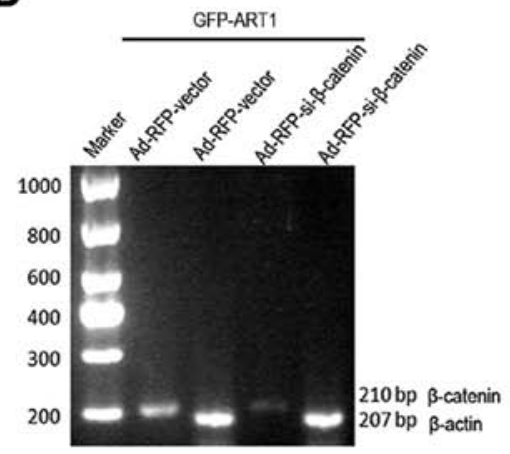

E

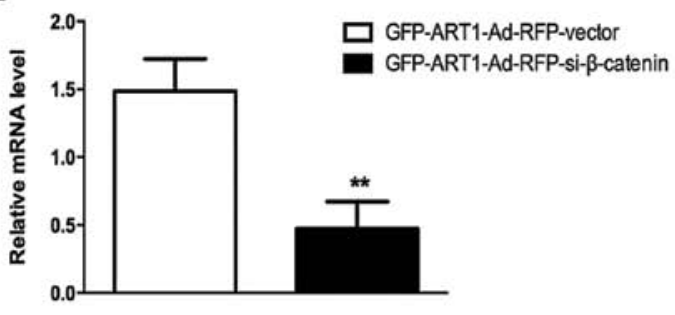

G

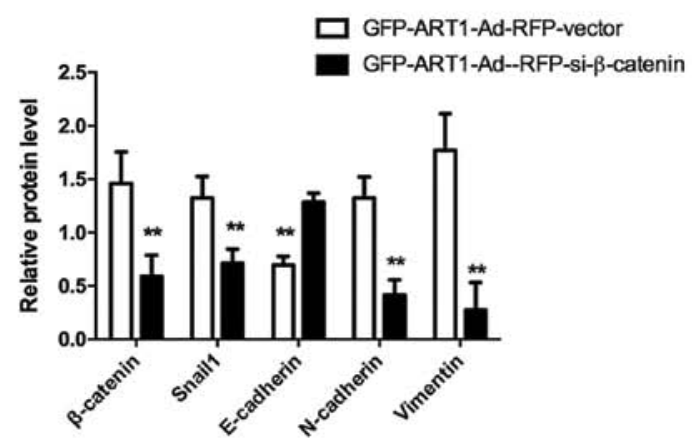

Figure 7. $\beta$-catenin is blocked by Ad-si- $\beta$-catenin in the GFP-ART1 group. (A and B) The GFP-ART1 CT26 cells were treated with LY294002. Compared with the untreated GFP-ART1 CT26 cells, the expression of phospho-Akt ${ }^{\text {ser473 }}$ and $\beta$-catenin was significantly decreased in the LY294002 treated GFP-ART1 CT26 cells $(* * \mathrm{p}<0.01)$. The expression of non-phosphorylation AKT was not significantly different between the treated and untreated GFP-ART1 CT26 cells ( $>0.05$ ). (C) The fluorescence of transfected GFP-ART1 CT26 cells was observed under the fluorescent microscope. (a) GFP-ART1-Ad-RFP-vector CT26 cells; (a1) white light; (a2) Ad-RFP-vector; (a3) GFP-ART1; and (a4) GFP-ART1+Ad-RFP-vector. (b) GFP-ART1-Ad-si- $\beta$-catenin; (b1) white light; (b2) Ad-RFP-si- $\beta$-catenin; and (b4) GFP-ART1+RFP-Ad-si- $\beta$-catenin. (D-G) Compared with GFP-ART1-Ad-RFP-vector, the mRNA and protein levels of $\beta$-catenin were significantly decreased and the expression of EMT related proteins (snaill, N-cadherin, and vimentin) was also markedly reduced, but the expression of E-cadherin was obviously increased in the GFP-ART1-Ad-RFP-si- $\beta$-catenin CT26 cells $\left({ }^{*} \mathrm{p}<0.05,{ }^{* *} \mathrm{p}<0.01\right)$.

tissues was higher than that in the adjacent tissues. Moreover, ART1 promoted CT26 cell proliferation via the RhoA/cfos/c-myc pathway and inhibited apoptosis by the PI3K/Akt/
$\mathrm{NF}-\kappa \mathrm{B}$ pathway in vitro $(23,24)$. However, there is no report on the role of ART1 in EMT and its correlation with invasion and metastasis of carcinoma. In this study, we found that over- 
A
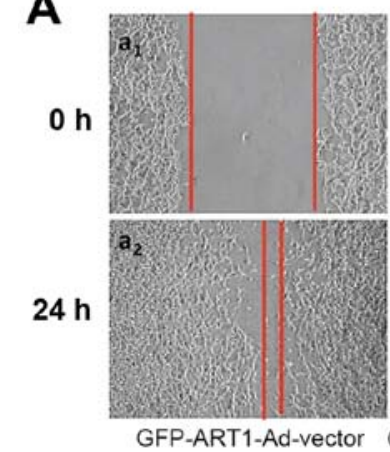

C

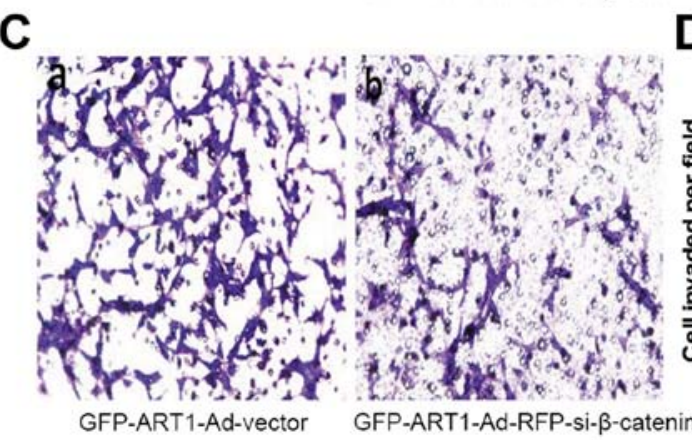

B
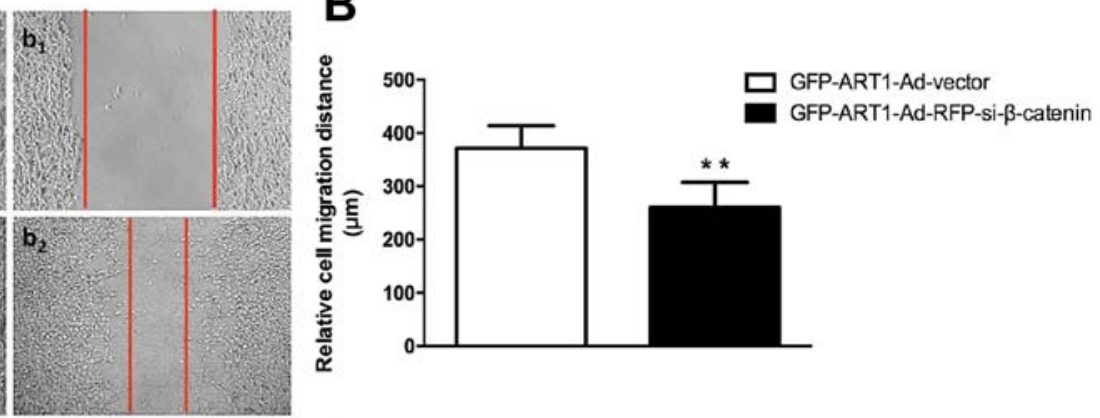
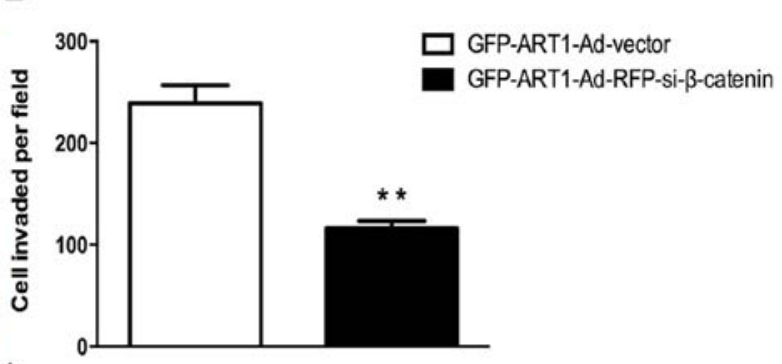

Figure 8. Effects of silencing $\beta$-catenin on migration and invasion in the GFP-ART1 CT26 cells. (A and B) Cell wound healing assay (x40 magnification): (a1 and a2) GFP-ART1-Ad-RFP-vector CT26 cells; (b1 and b2) GFP-ART1-Ad-RFP-si- $\beta$-catenin CT26 cells. Compared with the GFP-ART1-Ad-RFP-vector CT26 cells, the distance of cell wound healing was significantly decreased in the GFP-ART1-Ad-RFP-si- $\beta$-catenin CT26 cells ( ${ }^{* *}$ p $\left.<0.01\right)$. (C and D) Transwell invasion assay (x200 magnification). (a) GFP-ART1-Ad-RFP-vector CT26 cells; (b) GFP-ART1-Ad-RFP-si- $\beta$-catenin CT26 cells. Compared with the GFPART1-Ad-RFP-vector CT26 cells, the number of cells through the Matrigel-coated chamber membrane was observably decreased (** $<<0.01)$.

expression of ART1 in CT26 cells could promote the change of the cells from apical-basal polarized epithelioid cells to spindle-like and mesenchymal-like cells, but silencing ART1 in CT26 cells showed the opposite phenomenon. Therefore, we speculate that ART1 may be closely related to EMT in CT26 cells. The process of EMT is regulated by transcription inducers, such as snail, mesenchymal markers (vimentin, $\mathrm{N}$-cadherin) and the epithelial cells marker E-cadherin (32). To further verify the molecular mechanism of ART1 related to EMT, we found that upregulation of ART1 simultaneously enhanced expression of snail, vimentin and $\mathrm{N}$-cadherin and suppressed the expression of E-cadherin in CT26 cells and its xenograft tumor in the spleen. However, GFP-shART1 CT26 cells and its xenograft tumor in spleen showed the opposite effect. Additionally, we also observed that ART1 overexpression promoted the invasion, migration and adhesion abilities of CT26 cells. ART1 silencing showed inhibitory effects. To further verify that ART1 could affect tumor metastasis in vivo, we constructed a tumor transplantation model through inoculating CT26 cells under the splenic capsule of BALB/c mice and demonstrated that overexpressing ART1 could led to a significant promotion of tumor metastasis with a heavier liver weight and more metastasis nodules in mice. Silencing ART1 had the opposite effect. We presume that ART1 may affect the invasion, migration and adhesion of colorectal carcinoma by regulating EMT.

The Rho family belongs to the ras superfamily with GTP enzyme activity and it is not easy to change its expression in tumor cells. RhoA, whose mRNA and protein levels are overexpressed in a series of tumors, is one of the major Rho family members. Many researchers have suggested that RhoA is closely related to tumor development $(33,34)$. Rho associated coiled-coil containing kinase (ROCK) is a direct downstream effect factor of RhoA. The RhoA/ROCK pathway plays a central role in the reorganization of the actin cytoskeleton by affecting actin polymerization named F-actin. F-actin could affect the forming of microfilaments and stress fibers, and then influences the motility and morphogenesis of eukaryotic cells. Stable F-actin promoted actomyosin contractility and detach cells from the extracellular matrix (35-37). Therefore, the RhoA/ROCK pathway may regulate cytoskeleton reorganization and actomyosin-based cortical contractility, affecting mesenchymal migration (38), collectively suggesting that activation of RhoA promotes cytoskeleton reorganization and the progression of EMT. Meta-iodobenzyl guaniding (MIBG) is a specific competitive inhibitor of arginine-specific mono-ADP-ribosytransferase. It could inhibit vascular smooth muscle cell proliferation and migration through suppression of arginine-specific mono-ADP-ribosytransferases, which may be associated with decreasing the expression of RhoA (39). In these previous studies, we also showed that silencing ART1 could decrease the expression of RhoA in CT26 cells (23). Therefore, we deduced that ART1 might have a close relationship with the RhoA/ROCK pathway. In this study, ART1 overexpression is associated with an increase in expression of RhoA, ROCK1 and F-actin. Hence, ART1 maybe related to the Rho/ROCK pathway in the process of EMT.

The PI3K/AKT pathway participates in a variety of oncogenic processes, including cell proliferation, apoptosis, and EMT $(40,41)$. GSK-3 $\beta$ could be phosphorylated on Ser-473 by AKT and then inactivated (42). It has been reported that non-phosphorylated GSK- $3 \beta$ could boost the binding of phos- 
phorylated APC and Axin with $\beta$-catenin, contributing to the degradation of $\beta$-catenin $(43,44)$. Therefore, the increase of phosphorylated GSK- $3 \beta$ could help $\beta$-catenin evade degradation in the cytoplasm and then translocate into the nucleus. The nuclear accumulation of $\beta$-catenin serves as a cofactor with the transcription factor LEF/TCF (lymphoid enhancer factor/T cell factor) to mediate the transcription of EMT inducer snail which could bind to E-cadherin promoter at E-boxes resulting in the suppression on the transcription of E-cadherin and the increase of the expression of mesenchymal marker proteins $\mathrm{N}$-cadherin, and vimentin (32). In this study, GFP-ART1 CT26 cells and its intrasplenic tumor of BALB/c mice showed an increase in the expression of phospho-AKT, phospho-GSK-3 $\beta$, total $\beta$-catenin and nuclear $\beta$-catenin. GFP-shRNA ART1 CT26 cells and its intrasplenic tumor of BALB/c mice showed the opposite results. To further confirm whether ART1 could regulate $\beta$-catenin through the AKT pathway, the GFP-ART1 CT26 cells was treated with LY294002, an inhibitor of AKT phosphorylation. The results showed that expression of $\beta$-catenin in GFP-ART1 CT26 cells treated with LY294002 was observably decreased, compared to GFP-ART1 CT26 cells without LY294002. Therefore, ART1 may mediate the AKT pathway to influence the expression of $\beta$-catenin. To further verify that ART1 could influence EMT related factors and its downstream factors via $\beta$-catenin, the GFP-ART1 CT26 cells were successfully infected with si- $\beta$-catenin adenovirus vectors to decrease the expression of $\beta$-catenin in GFP-ART1 CT26 cells. We found that silencing $\beta$-catenin in the GFP-ART1 CT26 cells suppressed the invasion and migration abilities of GFP-ART1 CT26 cells. Importantly, expressions of snail1 $\mathrm{N}$-cadherin and vimentin in GFP-ART1 CT26 cells infected with si- $\beta$-catenin adenovirus vectors were also observably declined, and epithelial marker protein E-cadherin was increased, compared with GFP-ART1 CT26 cells without infection with si- $\beta$-catenin adenovirus vectors. These results suggest that the effect of ART1 on EMT may be associated with the PI3K/AKT/ $\beta$-catenin pathway.

However, the relationship between RhoA/ROCK and PI3K/ AKT pathways in EMT is not clear. Interestingly, many studies report a close link between the RhoA/ROCK and PI3K/AKT pathways. Nonetheless, these ideas on the relationship between two pathways vary in different cells. The RhoA/ROCK pathway could activate phosphatidylinositol 3-kinase (PI3k) and AKT in the cardiomyocyte (45). Myoblast survival is controlled by the PI3K-Akt signaling pathway, which is induced by RhoA (46). Plexin-B1, which mediates RhoA/ROCK to activate the PI3K/Akt pathway, enhancing the motility of endothelial cells (47). However, some researchers have suggested that RhoA is downstream of PI3K/AKT in HeLa cells and that it is derived from mTOR, one of the factors that is downstream of PI3K/ AKT that could stimulate GTP loading of RhoA in starved HeLa cells (48). Hence, the relationship between the RhoA/ ROCK and PI3K/AKT pathway remains unclear in CT26 cells. In this study, non-transfection CT26 cells that were treated with ROCK1 inhibitor and phospho-AKT (ser473) inhibitor respectively, indicated that the inhibition of ROCK1 could suppress the expression of phospho-AKT (ser473) in CT26 cells. However, inhibition of phospho-AKT could not affect the expression of ROCK1. These results suggested that ART1 regulates EMT related factors to influence the progres- sion of tumor via PI3K/AKT pathways, which may be affected by RhoA/ROCK signaling.

This study demonstrated that ART1 promoted CT26 cell invasion and metastasis through EMT in vivo and in vitro. Also, we showed that ART1 regulated the EMT of CT26 cells through activation of the RhoA-ROCK1-AKT- $\beta$-catenin pathway, which lead to cytoskeleton reorganization, a decrease in the expression of E-cadherin, an increase in expression of snail1, MMP-2, MMP-9, vimentin and N-cadherin. In conclusion, this is the first report on the effect of ART1 on tumor cell invasion and metastasis by regulating EMT. These new findings most likely indicate that ART1 could be a novel molecular therapeutic target for colorectal carcinoma. However, the effect of ART1 on tumor progression and its other exact molecular mechanisms require further research.

In conclusion, mono-ADP-ribosylation has been recognized as a key factor in disease including cancer. ART1 is an arginine specific mono-ADP-ribosylated transferase. The change of ART1 could reflect the role of arginine specific mono-ADP-ribosylation in development of colorectal carcinoma. Our data showed that the change of ART1 could affect the abilities of invasion and metastasis, induce EMT in mouse colorectal carcinoma CT26 cells. In addition, the concrete mechanism may relate to ART1 which regulate the RhoA/ ROCK1/AKT/ $\beta$-catenin pathway and its downstream factors (snail1, vimentin, N-cadherin and E-cadherin). ART1 as a new target for therapy in colorectal carcinoma and needs further in-depth study.

\section{Acknowledgements}

We thank Dr Jia-Yi Huang for the generous gift of adenovirus (Ad)-si- $\beta$-catenin. We also thank Professor Ya-Lan Wang for useful discussion and careful modification. This study was supported by the Ministry of Education Specialized Research Fund for the Doctoral Program of Higher Education (grant no. 20105503110009), the Science and Technology Program of Chongqing Municipal Education Commission (grant no. KJ110322) and the National Nature Science Foundation of China (NSFC: 30870946).

\section{References}

1. Micalizzi DS, Farabaugh SM and Ford HL: Epithelialmesenchymal transition in cancer: Parallels between normal development and tumor progression. J Mammary Gland Biol Neoplasia 15: 117-134, 2010.

2. Brabletz T, Hlubek F, Spaderna S, Schmalhofer O, Hiendlmeyer E, Jung A and Kirchner T: Invasion and metastasis in colorectal cancer: Epithelial-mesenchymal transition, mesenchymalepithelial transition, stem cells and $\beta$-catenin. Cells Tissues Organs 179: 56-65, 2005.

3. Cano A, Pérez-Moreno MA, Rodrigo I, Locascio A, Blanco MJ, del Barrio MG, Portillo F and Nieto MA: The transcription factor snail controls epithelial-mesenchymal transitions by repressing E-cadherin expression. Nat Cell Biol 2: 76-83, 2000.

4. Nagaishi M, Paulus W, Brokinkel B, Vital A, Tanaka Y, Nakazato Y, Giangaspero F and Ohgaki H: Transcriptional factors for epithelial-mesenchymal transition are associated with mesenchymal differentiation in gliosarcoma. Brain Pathol 22: 670-676, 2012.

5. Radisky ES and Radisky DC: Matrix metalloproteinase-induced epithelial-mesenchymal transition in breast cancer. J Mammary Gland Biol Neoplasia 15: 201-212, 2010.

6. Kleine $\mathrm{H}$ and Lüscher B: Learning how to read ADP-ribosylation. Cell 139: 17-19, 2009. 
7. Zolkiewska A: Ecto-ADP-ribose transferases: Cell-surface response to local tissue injury. Physiology (Bethesda) 20: 374-381, 2005.

8. Tuncel H, Tanaka S, Oka S, Nakai S, Fukutomi R, Okamoto M, Ota T, Kaneko H, Tatsuka M and Shimamoto F: PARP6, a mono (ADP-ribosyl) transferase and a negative regulator of cell proliferation, is involved in colorectal cancer development. Int J Oncol 41: 2079-2086, 2012.

9. Gangopadhyay NN, Luketich JD, Opest A, Visus C, Meyer EM, Landreneau R and Schuchert MJ: Inhibition of poly (ADP-ribose) polymerase (PARP) induces apoptosis in lung cancer cell lines. Cancer Invest 29: 608-616, 2011.

10. Inbar D, Cohen-Armon M and Neumann D: Erythropoietin-driven signalling and cell migration mediated by polyADP-ribosylation. Br J Cancer 107: 1317-1326, 2012.

11. Li M, Threadgill MD, Wang Y, Cai L and Lin X: Poly (ADP-ribose) polymerase inhibition down-regulates expression of metastasis-related genes in CT26 colon carcinoma cells. Pathobiology 76: 108-116, 2009.

12. Caldini R, Fanti E, Magnelli L, Barletta E, Tanganelli E, Zampieri $\mathrm{M}$ and Chevanne M: Low doses of 3-aminobenzamide, a poly (ADP-ribose) polymerase inhibitor, stimulate angiogenesis by regulating expression of urokinase type plasminogen activator and matrix metalloprotease 2. Vasc Cell 3: 12, 2011.

13. Giansanti V, Donà $F$, Tillhon $M$ and Scovassi AI: PARP inhibitors: New tools to protect from inflammation. Biochem Pharmacol 80: 1869-1877, 2010.

14. Wielckens K, Bredehorst R, Adamietz P and Hilz H: Protein-bound polymeric and monomeric ADP-ribose residues in hepatic tissues. Comparative analyses using a new procedure for the quantification of poly (ADP-ribose). Eur J Biochem 117: 69-74, 1981

15. Laing S, Unger M, Koch-Nolte F and Haag F: ADP-ribosylation of arginine. Amino Acids 41: 257-269, 2011.

16. Okazaki IJ and Moss J: Mono-ADP-ribosylation: A reversible posttranslational modification of proteins. Adv Pharmacol 35 247-280, 1996.

17. Jones EM and Baird A: Cell-surface ADP-ribosylation of fibroblast growth factor-2 by an arginine-specific ADP-ribosyltransferase. Biochem J 323: 173-177, 1997.

18. Hottiger MO, Boothby M, Koch-Nolte F, Lüscher B, Martin NM, Plummer R, Wang ZQ and Ziegler M: Progress in the function and regulation of ADP-Ribosylation. Sci Signal 4: mr5, 2011

19. Paone G, Wada A, Stevens LA, Matin A, Hirayama T, Levine RL and Moss J: ADP ribosylation of human neutrophil peptide-1 regulates its biological properties. Proc Natl Acad Sci USA 99: 8231-8235, 2002.

20. Saxty BA, Yadollahi-Farsani M, Upton PD, Johnstone SR and MacDermot J: Inactivation of platelet-derived growth factor-BB following modification by ADP-ribosyltransferase. Br J Pharmacol 133: 1219-1226, 2001.

21. Zolkiewska A and Moss J: Integrin alpha 7 as substrate for a glycosylphosphatidylinositol-anchored ADP-ribosyltransferase on the surface of skeletal muscle cells. J Biol Chem 268 25273-25276, 1993.

22. Kuang J, Wang Y-L, Xiao M, Tang Y, Chen WW, Song GL, Yang $\mathrm{X}$ and $\mathrm{Li} \mathrm{M}$ : Synergistic effect of arginine-specific ADP-ribosyltransferase 1 and poly (ADP-ribose) polymerase-1 on apoptosis induced by cisplatin in CT26 cells. Oncol Rep 31: 2335-2343, 2014.

23. Xu J-X, Wang Y-1, Tang Y and Xiong W: Effect of ART1 gene silencing by RNA interference on the proliferation of mouse colon carcinoma cells and its possible mechanism. Tumor 32 . 949-954, 2012

24. Xiao M, Tang Y, Wang Y-L, Yang L, Li X, Kuang J and Song GL: ART1 silencing enhances apoptosis of mouse CT26 cells via the PI3K/Akt/NF-кB pathway. Cell Physiol Biochem 32: 1587-1599, 2013.

25. Tang Y, Wang Y-L, Yang L, Xu JX, Xiong W, Xiao M and $\mathrm{Li}$ M: Inhibition of arginine ADP-ribosyltransferase 1 reduces the expression of poly (ADP-ribose) polymerase-1 in colon carcinoma. Int J Mol Med 32: 130-136, 2013

26. Shen L, Zhang X, Hu D, Feng T, Li H, Lu Y and Huang J: Hepatitis B virus $\mathrm{X}(\mathrm{HBx})$ play an anti-apoptosis role in hepatic progenitor cells by activating Wnt $/ \beta$-catenin pathway. Mol Cell Biochem 383: 213-222, 2013.
27. Jinka R, Kapoor R, Sistla PG, Raj TA and Pande G: Alterations in cell-extracellular matrix interactions during progression of cancers. Int J Cell Biol 2012: 219196, 2012.

28. Vizirianakis IS, Yao C-C, Chen Y, Ziober BL, Tsiftsoglou AS and Kramer RH: Transfection of MCF-7 carcinoma cells with human integrin $\alpha 7 \mathrm{cDNA}$ promotes adhesion to laminin. Arch Biochem Biophys 385: 108-116, 2001.

29. Kramer RH, Vu MP, Cheng Y-F, Ramos DM, Timpl R and Waleh N: Laminin-binding integrin alpha 7 beta 1: Functional characterization and expression in normal and malignant melanocytes. Cell Regul 2: 805-817, 1991.

30. Yao C-C, Ziober BL, Squillace RM and Kramer RH: $\alpha 7$ integrin mediates cell adhesion and migration on specific laminin isoforms. J Biol Chem 271: 25598-25603, 1996.

31. Zhao Z, Gruszczynska-Biegala J and Zolkiewska A: ADP-ribosylation of integrin alpha7 modulates the binding of integrin alpha7beta1 to laminin. Biochem J 385: 309-317, 2005.

32. Batlle E, Sancho E, Francí C, Domínguez D, Monfar M, Baulida J and García De Herreros A: The transcription factor snail is a repressor of E-cadherin gene expression in epithelial tumour cells. Nat Cell Biol 2: 84-89, 2000.

33. Sahai E and Marshall CJ: RHO-GTPases and cancer. Nat Rev Cancer 2: 133-142, 2002.

34. Rathinam R, Berrier A and Alahari SK: Role of Rho GTPases and their regulators in cancer progression. Front Biosci (Landmark Ed) 16: 2561-2571, 2011.

35. Yamazaki D, Kurisu S and Takenawa T: Regulation of cancer cell motility through actin reorganization. Cancer Sci 96: 379-386, 2005.

36. Watanabe N, Madaule P, Reid T, Ishizaki T, Watanabe G, Kakizuka A, Saito Y, Nakao K, Jockusch BM and Narumiya S: p140mDia, a mammalian homolog of Drosophila diaphanous, is a target protein for Rho small GTPase and is a ligand for profilin. EMBO J 16: 3044-3056, 1997.

37. Gomez dPT and Lacal JC: RHOA (ras homolog gene family, member A). Atlas Genet Cytogenet Oncol Haematol 11: 124-127, 2007.

38. Vega FM and Ridley AJ: Rho GTPases in cancer cell biology. FEBS Lett 582: 2093-2101, 2008

39. Yau L, Litchie B, Thomas S, Storie B, Yurkova N and Zahradka P: Endogenous mono-ADP-ribosylation mediates smooth muscle cell proliferation and migration via protein kinase $\mathrm{N}$-dependent induction of c-fos expression. Eur J Biochem 270: 101-110, 2003.

40. Osaki M, Oshimura M and Ito H: PI3K-Akt pathway: Its functions and alterations in human cancer. Apoptosis 9: 667-676, 2004.

41. Cho HJ, Baek KE, Saika S, Jeong M-J and Yoo J: Snail is required for transforming growth factor- $\beta$-induced epithelialmesenchymal transition by activating PI3 kinase/Akt signal pathway. Biochem Biophys Res Commun 353: 337-343, 2007

42. Qiao M, Sheng S and Pardee AB: Metastasis and AKT activation. Cell Cycle 7: 2991-2996, 2008.

43. Rubinfeld B, Albert I, Porfiri E, Fiol C, Munemitsu S and Polakis P: Binding of GSK $3 \beta$ to the APC- $\beta$-catenin complex and regulation of complex assembly. Science 272: 1023-1026, 1996.

44. Yamamoto H, Kishida S, Kishida M, Ikeda S, Takada S and Kikuchi A: Phosphorylation of axin, a Wnt signal negative regulator, by glycogen synthase kinase- $3 \beta$ regulates its stability. J Biol Chem 274: 10681-10684, 1999.

45. Del Re DP, Miyamoto S and Brown JH: Focal adhesion kinase as a RhoA-activable signaling scaffold mediating Akt activation and cardiomyocyte protection. J Biol Chem 283: 35622-35629, 2008.

46. Reuveny M, Heller $\mathrm{H}$ and Bengal E: RhoA controls myoblast survival by inducing the phosphatidylinositol 3-kinase-Akt signaling pathway. FEBS Lett 569: 129-134, 2004.

47. Basile JR, Gavard J and Gutkind JS: Plexin-B1 utilizes RhoA and Rho kinase to promote the integrin-dependent activation of Akt and ERK and endothelial cell motility. J Biol Chem 282: 34888-34895, 2007.

48. Jacinto E, Loewith R, Schmidt A, Lin S, Rüegg MA, Hall A and Hall MN: Mammalian TOR complex 2 controls the actin cytoskeleton and is rapamycin insensitive. Nat Cell Biol 6: 1122-1128, 2004. 